\title{
Evaluation of quinoa (Chenopodium quinoa Willd) flour fortification on the quality of pasta production
}

\author{
Mona Y. Mostafa
}

Home Economics Department, Faculty of Specific Education, Mansoura University, Egypt

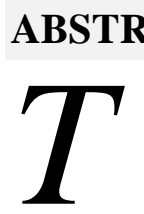

he aim of the present investigation was to formulate a pasta product with increased levels of protein and nutritive value by adding quinoa flour to traditional durum wheat semolina. And studding the effects of fortification on farinograph parameters, color characteristics, cooking quality, consumer acceptance, texture profile and chemical composition, and the most desirable ratio of quinoa flour is to be determined. Pasta was fortified with 10, 20 and 30\% quinoa flour (QF) and evaluated against a control made of $100 \%$ semolina flour (control) for farinograph parameters, color characteristics, cooking quality, consumer acceptance, texture profile and chemical composition. Fortification pasta dough with QF at 10, 20 and $30 \%$ gradually increased water absorption, mixing tolerance index and dough weakening, meanwhile decreased the arrival time, dough development time and dough stability scores gradually comparing with those of pasta control sample. Pasta was darker and more brown in color ( $L^{*}$ and $b^{*}$ values decreased while $a^{*}$ values increased) with the increased addition of quinoa flour. Pasta products containing quinoa flour had an increased weight and volume than control gradually by increasing $Q F$. Cooking loss of fortified pastas was significantly $(p<0.05)$ greater than the control, but were within the acceptable range of 7-8\%. The untrained consumer panel significantly $(p<0.05)$ preferred the control pasta over those fortified with quinoa flour. All pasta variations were deemed acceptable in sensory study. Hardness of pasta increased as the percentage of quinoa fortification increased. Quinoa flour had adverse effects on protein, fat, ash and fiber content when compared to control. It can be recommended that fortification with different percentages of quinoa flour produces high nutritional value and high protein pasta.

Keywords: Pasta, Quinoa, Farinograph, Cooking quality, Hardness. 
Evaluation of quinoa (Chenopodium quinoa Willd.) flour fortification on the quality of pasta production

Mona Y. Mostafa

\section{INTRODUCTION}

Quinoa, or chenopodium quinoa, is a member of the Amaranthaceae plant family. Although it is a flowering plant, quinoa's grass-like uses and qualities cause it to be considered a pseudocereal. Quinoa grains can be used for many things. They can be toasted, ground into flour, boiled and added to soup, or cooked and served similar to rice. Quinoa flour can be used to make pasta or breads. Unlike cereals, quinoa has a soft outer layer that does not need to be removed before milling. This allows quinoa to yield roughly 100\% flour (Fleming and Galwey 1995; Jacobsen, 2011; James, 2009 and Alvez et al., 2010).

Studies have shown that quinoa is a good source of quality protein (10.4$17.0 \%)$ dietary fiber, polyunsaturated fats, and minerals (FAO, 2014). It has been found to contain between $10-21 \%$ protein, with most products averaging around 13\% (Fleming and Galwey, 1995; Bhargava et al., 2005). These fats are shown to maintain their quality due to the prevalence of vitamin $E$, a natural antioxidant (Su-Chuen et al., 2007; Abugoch, 2009).

Quinoa content is rich in vitamin $\mathrm{A}, \mathrm{B} 2, \mathrm{E}$ and minerals such as calcium, iron, zinc, magnesium and manganese, which give the grains high value for different target populations: for instance, adults and children benefit from calcium for bones and from iron for blood functions (Koziol, 1992 and Repo-Carrasco et al., 2003)

Quinoa has some functional (technological) properties like solubility, water-holding capacity (WHC), gelation, emulsifying, and foaming that allow diversified uses (Gorinstein et al., 2008). Quinoa starch has physicochemical properties (such as viscosity, freeze 
Evaluation of quinoa (Chenopodium quinoa Willd.) flour fortification on the quality of pasta production

Mona Y. Mostafa

stability) which give it functional properties with novel uses (James 2009). There are several developments with quinoa flour at a smaller scale, like bread, cookies, muffins, pasta, snacks, drinks, flakes, breakfast cereals, baby foods, beer, diet supplements, and extrudates (Linnemann and Dijkstra, 2002; Dogan and Karwe, 2003 and Bhargava et al., 2006). Nsimba et al. (2008) used quinoa and amaranth in products such as bread, pastas and baby foods. The seeds are small and have been used as flour, toasted, added to soups, or made into bread. Quinoa is highly nutritive and is being used to make flour, soup, breakfast and alcohol. It is sold either as whole grain that is cooked as rice or in combination dishes (Galwey, 1989).

Due to its low price, ease of preparation, stable shelf life, and overall versatility, pasta is consumed by many people worldwide. Having originated in Asia and the Mediterranean, Italy is still most well-known for its pasta making and leads in national consumer consumption per capita. The versatility of pasta allows it to be formed into almost any shape and size. It comes in varieties such as spaghetti, fettuccine, macaroni, rotini, and farfalle. It can even be stuffed with meats or cheeses to make ravioli. Pasta is prepared in two styles, fresh or dried. Fresh pasta eliminates the drying step and allows for a much quicker product to be made, but has only a portion of the shelf life of dried pasta (Marconi and Carcea 2001; International Pasta

Organization 2012; Savita et al., 2013).

Pasta is a source of carbohydrates (74-77\%, dry basis) with low glycaemic index (GI) (Monge et al 1990). Pasta also contains $11-15 \%$ proteins but is deficient in lysine and threonine (the first and second limiting amino acids), 
Evaluation of quinoa (Chenopodium quinoa Willd.) flour fortification on the quality of pasta production

Mona Y. Mostafa

common to most cereal products (Abdel-Aal and

Hucl, 2002). This provides an opportunity for the use of non-traditional raw materials to increase the nutritional quality of pasta (Del Nobile et al., 2005). Consequently, legumes and cereals are nutritionally complementary (Duranti 2006).

Aim of work: Therefore the present investigation was carried out to assess the pasta quality by enriching with quinoa seeds as a protein source.

\section{MATERIALS \& METHODS}

\section{Materials}

Semolina (Triticum durum) was procured from the local market. Quinoa seeds (Chenopodium quinoa Willd.) were obtained from National Research Center, Giza, Egypt. The quinoa seeds were treated by washing and polishing to remove an outer coat containing bitter saponins (Dini et al., 2002). Then,

seeds grinded until become soft powder.

\section{Methods}

Pasta preparation: Pasta samples were produced by hand in a homemade style. The control sample was made from $100 \%$ semolina flour (SF), while three different samples were made by replacing 10, 20 and $30 \% \mathrm{SF}$ with quinoa flour (QF) as follow:

Control: Pasta control prepared with $100 \%$ SF.

10\% QFP: Pasta prepared with $90 \% \mathrm{SF}$ and $10 \% \mathrm{QF}$.

20\% QFP: Pasta prepared with $80 \%$ SF and $20 \%$ QF.

30\% QFP: Pasta prepared with $70 \% \mathrm{SF}$ and $30 \% \mathrm{QF}$.

The dry ingredients were combined into a homogenous mixture and poured onto a clean, smooth work area. Warm water at approximately $32-49^{\circ}$ Celsius was slowly poured into a well formed in the center of the mounded flour. The water 
was incorporated by pulling flour from the inside wall using a fork. Once all the water was added and mixing with a fork became difficult, the remaining flour was blended in by hand. The crumbly dough mass was then kneaded for approximately 10 minutes, forming a smooth, elastic dough. Kneading was done by the repeated action of flattening the dough with the palm of the hand, rotating the dough, and folding over. The kneaded dough was wrapped in plastic film and set to rest at room temperature for one hour. Once rested, the dough ball was divided into two pieces for processing. Each dough piece was flattened and sent through the pasta machine (Imperia Tipo Lusso SP150, Torino, Italy) starting on the thickest setting (number 1). The dough was folded into thirds and sent through again. It was then folded in half, run through, and cut into manageable lengths. Sheets of dough were fed through the pasta machine at decreasing thicknesses (numbers 2, 3, and 4, respectively). The thin, flattened sheets were laid to dry for 10 minutes before being passed through the fettuccine cutter. The cut strands were laid on wire racks and covered with a towel to dry overnight. The dried pasta was stored in bags at room temperature until further use.

\section{Analytical Methods:}

\section{Chemical composition:}

Moisture, ash, crude protein, fat and crude fiber contents were determined according to the methods outlined in AOAC (2000).

Carbohydrates were calculated by difference as mentioned as follows: Carbohydrates $=100-(\%$ protein $+\%$ fat $+\%$ ash $+\%$ crude fiber).

\section{Rheological properties:}

Rheological properties of dough were evaluated using Farinograph according to AACC (2000). 
Evaluation of quinoa (Chenopodium quinoa Willd.) flour fortification on the quality of pasta production

Mona Y. Mostafa

\section{Color}

measurement:

Objective evaluation of color of pasta samples was measured in the National Research Center, Giza, Egypt. Hunter

L*(luminosity), $\mathrm{a}^{*}$ (red intensity), and $b^{*}$ (yellow intensity).

Sensory evaluation: Sensory evaluation of cooked pasta was evaluated as described by Hussein et al. (2006).

Cooking quality of pasta: Cooking quality of pasta were carried out by measuring the increases in weight, volume and cooking loss after cooking according the methods of AACC (2000).

Texture profile analysis of Pasta: Hardness, Deformation at hardness, Peak Stress and Fracturability with $1 \%$ of load sensitivity analysis of uncooked and cooked pasta samples was conducted using The TVT Texture Analyzer (Perten instruments) according to TVT Method 10.0 following the method described by Tang et al. (1999). Data was obtained, calculated, and graphed using the texture analyzer PC software program Texture Expert Exceed (Version 2.62, Texture Technologies Corp., and Scarsdale, NY) to assess the effect of quinoa flour on textural attributes.

Statistical evaluation: The obtained results were evaluated statistically using analysis of variance as reported by McClave \& Benson (1991).

\section{RESULTS \& DISCUSSION}

Data in Table 1 show a comparison between Chemical composition contents of semolina flour (SF) and quinoa flour (QF). $\mathrm{SF}$ recorded $10.81 \pm 0.70$, $13.10 \pm 0.50,3.36 \pm 0.07,5.43$ $\pm 0.01,67.29 \pm 1.25$ and 6.31 $\pm 0.15 \%$ for moisture, crude protein, total fats, total ash, total carbohydrates and crude fiber, respectively. Meanwhile, QF recorded $10.78 \pm 0.07,13.99 \pm 0.14$, 
$3.87 \pm 0.01,6.08 \pm 0.02,65.44$ \pm 0.39 and $7.14 \pm 0.08 \%$ for the same previous parameters, respectively. It could be observed from results that QF had the higher contents of protein, fat, ash and fiber as compared to those of SF. These results were with accordance with USDA (2013) which stated that quinoa flour contained (13.28 $\mathrm{g}$ moisture, $368 \mathrm{kcal}$ energy, $14.12 g$ protein, 6.07 $g$ total lipid, $2.38 g$ ash, 64.16 $g$ carbohydrate, $7.0 \mathrm{~g}$ fiber) $g$ per $100 \mathrm{~g}$. While semolina flour contained (12.67 g moisture, $360 \mathrm{kcal}$ energy, $12.68 \mathrm{~g}$ protein, $1.05 \mathrm{~g}$ fat, $0.77 g$ ash and $72.83 g$ carbohydrates) $g$ per $100 \mathrm{~g}$.

\section{Quinoa flour}

contained $11.2 \%$ moisture, $13.5 \%$ crude protein, $6.3 \%$ ether extract, $9.5 \%$ crude fibre, $1.2 \%$ total ash and $58.3 \% \quad$ carbohydrate (Ogungbenle, 2003). The protein content of quinoa is higher than in cereals and ranges from 14 to $18 \%$ of the seed, as compared to maize
$(10 \%)$, rice $(8 \%)$ and wheat (14\%) (Koziol, 1992).

Farinograph parameters of four different pasta dough formulas (semolina flour, semolina flour with 10, 20 and $30 \%$ quinoa flour) were represented in Table 2. These pasta formulas regarding were evaluated for water absorption, arrival time, dough development time, dough stability, mixing tolerance index and dough weakening. Data show that fortification pasta dough with QF at 10, 20 and 30\% caused a gradually increasing in mixing tolerance index and dough weakening comparing to pasta control. Meanwhile, the arrival time, dough development time and dough stability values were decreased gradually by the increasing of quinoa flour in pasta dough. 20 and 30\% QF increased water absorption compared to control pasta.

Svec et al. (2011) investigated dough rheological properties and bread quality from 
Evaluation of quinoa (Chenopodium quinoa Willd.) flour fortification on the quality of pasta production

Mona Y. Mostafa

wheat/quinoa composite flour made at rates from 0 to $30 \%$ supplements. Quinoa wholemeal incorporation in wheat flour did not influenced water absorption, but dough stability decreased dependently to basic flour quality and quinoa additions similarly to Jancurová $\boldsymbol{e t}$ al. (2009). During dough kneading, up to $33 \%$ shorter development time and 50\% dough stability with twofold breakdown were recorded for Q30. Contrary to that, Jancurová et al. (2009) described independence of development time on quinoa level and also dough stability prolongation.

\section{Color characteristics} were measured in pasta samples at four stages (the flour mixture before processing, pasta after processing before drying, dried pasta and pasta after cooking) and the obtained data were tabulated in Table 3.

Generally, the fortification of pasta with quinoa flour caused a significant decreasing $(\mathrm{p}<0.05)$ in brightness $\left(L^{*}\right.$ value) at all previous stages of pasta processing comparing with the control pasta which was significantly lighter than other samples. This decrease in brightness of pastas containing legume flours is in accordance with many researchers who have experimented with legumes such as chickpea, green pea, yellow pea, split pea, faba bean, soy, and lentil, as well as pseudo-cereals like quinoa (Lorenz et al., 1993, Ugarcic-Hardi et al., 2003, Zhao et al., 2005, Wood 2009, Petitot et al., 2010b). Ugarcic-Hardi et al. (2003) attributed the decrease in brightness to a higher ash content in legume flours.It is known that consumers prefer bright yellow translucent pasta products, but the limit of acceptable brightness is undefined.

Similar to lightness decreasing, redness increased ( $a^{*}$ value increased) as more 
Evaluation of quinoa (Chenopodium quinoa Willd.) flour fortification on the quality of pasta production

Mona Y. Mostafa

quinoa flour was added. It can be concluded that the amount of quinoa flour added to pasta significantly affects redness of the product. The control pasta was found to be the most yellow (highest $b^{*}$ value), with yellowness significantly $\quad(\mathrm{p}<0.05)$ decreasing as more quinoa flour was added. This is in accordance with other researchers who have seen a decrease in yellowness of pastas containing chickpea, green pea, yellow pea, lentil, and quinoa flours (Lorenz $\boldsymbol{e t}$ al., 1993, Zhao et al., 2005, Wood 2009). This decrease in yellowness may be due to the leaching and/or degradation of color pigments, such as carotenoids and xanthophyll (Wood, 2009).

Similar results were found by Petitot et al., (2010b) where pasta fortified with faba bean flour saw a significant increase in redness. Petitot et al., (2010b) also noted that yellowness ( $b^{*}$ values) was not affected in this change. This is important to note because according to Ugarcic-Hardi et al., (2003), bright yellow pasta is achieved by having both high $b^{*}$ values and low $a^{*}$ values.

The effect of quinoa flour (QF) fortification of pasta weight increase, volume increase and cooking loss percentage were studied and the obtained data was tabulated in Table 4. A significant increase $(\mathrm{p}<0.05)$ were observed in weight and volume increase values gradually by increasing QF percentage in pasta. Weight increase percentage recorded $235 \pm 3.00, \quad 255 \pm 4.32$ and $275 \pm 5.33 \%$ for pasta with 10 , 20 and $30 \%$ QF, respectively. On the other hand, while volume increase percentage recorded $180 \pm 3.20,195 \pm 5.60$ and $210 \pm 3.55$ for pasta with 10,20 and $30 \% \mathrm{QF}$, respectively, meanwhile control pasta made with $100 \%$ SF recorded $220 \pm 2.80$ and $165 \pm 4.42$ for weight and volume increase percentage, 
Evaluation of quinoa (Chenopodium quinoa Willd.) flour fortification on the quality of pasta production

Mona Y. Mostafa

respectively. Cooking loss was significantly $\quad(\mathrm{p}<0.05)$ affected by the addition of QF. The control pasta made with $100 \%$ SF recorded significant $\quad(\mathrm{p}<0.05) \quad$ less cooking loss $(3.5 \pm 0.14)$ comparing with pasta containing QF. It could be noticed that the cooking loss values increase gradually by the increasing of $\mathrm{QF}$ percentage as recorded $5.00 \pm 0.21, \quad 6.5 \pm 0.28$ and $7.5 \pm 0.42$ for pasta samples with 10, 20 and $30 \%$ QF. This is in accordance with Bahnassey and Khan (1986) and Lorenz et al. (1993), who found that cooking loss increased as the level of fortification increased.

Fortifying pasta with legume flours (pea, lupin, chickpea, lentil, split pea, or faba bean) increases cooking loss (Nielson et al., 1980, RayasDuarte et al., 1996, Zhao et al., 2005 and Petitot et al., 2010b). Also, Lorenz et al. (1993) also found that adding quinoa flour to pasta resulted in a higher cooking loss than the control made from wheat flour. Duszkiewicz et al. (1988) observed higher water absorption and cooking loss in spaghetti blended with legume flour and concentrates. Legume supplementation of pasta resulted in greater cooking loss when compared to control (Bahnassey and Khan, 1986)

The addition of quinoa flour was significantly $(p<0.05)$ affected consumer acceptance of the pasta products. The average scores given by panelists in color, flavor, mouthfeel, elasticity and overall acceptability can be seen in Table 5. The control pasta was significantly $(\mathrm{p}<0.05)$ more liked than pastas containing quinoa flour. The least favored pasta was $30 \%$ quinoa flour pasta. This may be due to the poor textural properties of the samples. Of the fortified pastas, $10 \%$ quinoa flour pasta was found to be the most favored.

These results are in accordance with other 
Evaluation of quinoa (Chenopodium quinoa Willd.) flour fortification on the quality of pasta production

Mona Y. Mostafa

researchers who found that pasta made from 100\% semolina flour received the highest overall acceptability when compared to pastas supplemented with legume and pseudo-cereal flours (Bahnassey and Khan 1986, Zhao et al., 2005; Mastromatteo et al., 2011). Quinoa has been incorporated into wheat noodles (Lorenz et al., 1993). No statistically significant difference was found between noodles made with $10 \%$ and $30 \%$ quinoa. Noodles with $50 \%$ quinoa content were ranked least acceptable. Quinoa flour was extruded with corn grits to produce expanded snack products. Addition of quinoa produced a darker, less yellow extruded product. The products were rated as moderately acceptable

(Coulter \& Lorenz, 1991a, 1991b; Lorenz et al., 1995).

Texture profile of dried and cooked pasta was represented in Table 6 . Hardness of the pastas was affected by the fortification of pasta with quinoa flour. Hardness is the height of the force peak of the first compression cycle (Bourne 2002). In this study, it is the maximum force required to compress the dried pasta samples recorded 17.55, $32.30,34.32$ and $48.32 \mathrm{~N}$ for control sample, 10, 20 and $30 \%$ quinoa flour pasta, respectively. Meanwhile, the maximum force required to compress the cooked pasta samples recorded 3.02, 3.47, 3.86 and 4.09 for control sample, 10,20 and $30 \%$ quinoa flour pasta, respectively.

The control pasta (dried or cooked) was found to be less hard than the fortified pasta products. Pasta formula fortified with $30 \%$ quinoa flour was harder than pastas with 10 and $20 \%$ quinoa flours. The addition of quinoa flour has a greater effect on cooked and dried pasta hardness. These results are similar to those found by Petitot et al., (2010b) where pasta fortified with $35 \%$ 
legume flours (split pea or faba bean) significantly increased the hardness of pasta, which they attributed to increased protein content and decreased water uptake. In 1993, Lorenz et al. experimented with adding 10 , 30 , and $50 \%$ quinoa flour to wheat pasta. The addition of quinoa required more water for mixing, made the pasta darker in color, and increased cooking loss. Pasta made with $50 \%$ quinoa flour was shown to be poor in flavor and texture and was deemed unacceptable (Lorenz et al., 1993).

Data in Table 7 show the effect of substitution of 10,20 and $30 \%$ of semolina flour (SF) by quinoa flour (QF) on the chemical composition of processed pasta comparing with the control sample. Results show that the fortification pasta with QF increased significantly $(\mathrm{p}<0.05)$ the protein, fat, ash and fiber contents of pasta comparing with control pasta sample. On the other hand, the addition of QF caused a significant decreasing $\quad(\mathrm{p}<0.05) \quad$ in moisture and carbohydrates contents of processed pasta. These results due to the higher contents of protein, fat and ash of quinoa flour comparing with semolina flour. In quinoa flour pasta (QFP), protein contents recorded

$11.19 \pm 0.22$ 10.07 \pm 0.07 , $12.36 \pm 0.01 \%$, while fat contents recorded $1.71 \pm 0.07$, $2.23 \pm 0.07$ and $2.80 \pm 0.10 \%$ for 10, 20 and $30 \%$ QFP, respectively comparing with semolina flour pasta which recorded $9.13 \pm 0.07$ and $1.19 \pm 0.03 \%$ for protein and fat, respectively.

It could be noticed that the pasta sample with $30 \%$ QF caused an obvious increasing in protein, ash, fat and fiber contents comparing with other pasta samples. The results agreed with other research workers, Gurpreet et al. (2011); Young-SooKim (1998); Osorio et al. (2008); Bahnassey and 
Evaluation of quinoa (Chenopodium quinoa Willd.) flour fortification on the quality of pasta production

Mona Y. Mostafa

Khan (1986) who reported the incorporation of plant proteins flour increased the protein, fibre and ash contents of the final products.

\section{CONCLUSION}

The pasta product with the most beneficial ratio of quinoa flour is that containing $30 \%$ quinoa flour. It had the highest protein, fat,

\section{REFERENCES}

AACC (2000):

Approved methods of the AACC (10th ed.). St Paul, MN: American Association of Cereal Chemists.

AOAC (2000):

Official Methods of Analysis.15th Ed. Association of Official Analytical Chemists, Inc., Virginia, USA, pp: 770-771.

\section{Abdel-Aal ESM and Hucl $P$ (2002):}

ash and fiber contents. Pasta samples cooking loss was found to be in an acceptable range, and besides the texture attributes were not adversely affected by fortification. The color characteristics of pasta $10 \%$ QF were also nearly to that of the control, leading to a high level of visual acceptability.

Amino acid composition and in vitro protein digestibility of selected ancient wheats and their end products. Journal of Food Composition and Analysis, 15(6): 737747.

Abugoch LE (2009):

Quinoa (Chenopodium quinoa Willd.): composition, chemistry, nutritional, and functional properties. Adv. Food Nutr. Re.,s 58:1-31. 
Evaluation of quinoa (Chenopodium quinoa Willd.) flour fortification on the quality of pasta production

Mona Y. Mostafa

Alvez AV; Miranda M;

Vergara $J$; Uribe $E$;

Puenteb $L$ and

AMart'inezc E (2010):

Nutrition facts and

functional potential of quinoa (Chenopodium

quinoa willd.), an

ancient Andean grain: a review. $J$ Sci. Food Agric., 90: 2541-2547.

\section{Bahnassey Y and Khan K} (1986):

Fortification of spaghetti with edible legumes. II. Rheological, processing, and quality evaluation studies. Cereal Chem., 63(3):216-19.

Bhargava A; Rana TS; Shukla $S$ and Ohri D (2005):

Seed protein

electrophoresis of some cultivated and wild species of

Chenopodium. Biol. Plant, 49:505-511.

Bhargava A; Shukla S and Ohri, D (2006):
Chenopodium quinoaAn Indian perspective. Ind. Crops Prod., 23: 73-87.

Bourne MC (2002):

Principles of objective texture measurement. In: Bourne MC, editor. Food texture and viscosity: concept and measurement. 2nd ed. California: Academic Press. p107-88.

Coulter $\mathbf{L}$ and Lorenz $K$ (1991a):

Extruded com gritsquinoa blends. 1. Proximate composition, nutritional properties and sensory evaluation. Journal of Food Processing and Preservation, 15:231242.

Coulter $\mathbf{L}$ and Lorenz $\mathrm{K}$ (1991b):

Extruded com gritsquinoa blends. II. Physical characteristics of extruded products. Journal of Food 
Evaluation of quinoa (Chenopodium quinoa Willd.) flour fortification on the quality of pasta production

Mona Y. Mostafa

Processing and

Preservation, 15: 243259.

Del Nobile M A; Baiano A; Conte $A$ and Mocci G (2005):

Influence of protein content on spaghetti cooking quality. Journal of Cereal Science, 41: 347-356.

Dick JW and Youngs VL (1988):

Evaluation of durum wheat, semolina, and pasta in the United States. In: Fabriani G, Lintas C, editors. Durum wheat: chemistry and technology. St. Paul, MN: AACC. p237-248.

Dini I; Tenore GC and Dini, A (2002):

Oleanane saponins in "kancolla", a sweet variety of Chenopodium quinoa. Journal of Natural Products, 65: 1023-1026.
Dogan $H$ and Karwe $M$ (2003):

Physicochemical

properties of quinoa extrudates. Food Sci. Techn. Int., 9: 101-114.

Duranti M (2006):

Grain legume proteins and nutraceutical properties. Fitoterapia, 77(2): 67-82.

Duszkiewicz, R, Khan, K, Dick JW and Holm Y (1988):

Shelf life stability of spaghetti fortified with legume flours and protein concentrates, Cereal Chemistry, 65: 278-281.

FAO STAT (2014):

Food and Agricultural Organization of the United Nations; [Accessed 2014 Mar 24]. Available from: http://faostat.fao.org. 
Evaluation of quinoa (Chenopodium quinoa Willd.) flour fortification on the quality of pasta production

Mona Y. Mostafa

Fleming FE and Galwey NW (1995):

Quinoa (chenopodium quinoa). In: Williams JT. Cereals and pseudocereals. London: Chapman \& Hall. p384.

Galwey NW (1989):

Exploited plantsQuinoa. Biologist, 36 (5):267-274.

Gorinstein S; Lojek A; Cr̂z

M; Pawelzik E; DelgadoLicon E; Medina O; Moreno M; Salas I and Goshev I (2008):

Comparison of composition and antioxidant capacity of some cereals and pseudocereals. Int. J. Food Sci. Technol., 43: 629-637.

Gurpreet Kour; Savita Sharma $S$ and Nagi HPS (2011):

Enrichment of pasta with different plant proteins.

Hussein AMS; Mustafa BE and Moharrum HA(2006):

Preparation and evaluation of instant noodles made from wheat, rice, sorghum flours and their blends. Bulletin of the National Nutrition Institute, 29: 24-32.

International

Organization

Oct (2012):

[Accessed 2014 Mar 4]. Available from: www.internationalpasta. org.

Jacobsen SE (2011):

The Situation for quinoa and its production in Southern Bolivia: from Economic Success to environmental Disaster. Journal of Agronomy and Crop Science., 
Evaluation of quinoa (Chenopodium quinoa Willd.) flour fortification on the quality of pasta production

Mona Y. Mostafa

doi:10.1111/j.1439-

037X.2011.00475.x.

James L E A (2009):

Quinoa (Chenopodium quinoa Willd.):

Composition,

Chemistry, Nutritional, and Functional

Properties. Food and Nutrition Research, 58:1-32.

\section{Jancurová M; Minaroviová}

$L$ and Dandár A (2009):

Rheological properties of doughs with buckwheat and quinoa additives. Chemical Papers, 63(6): 738-741.

\section{Koziol MJ (1992):}

Chemical composition and nutritional evaluation of quinoa (Chenopodium quinoa Willd.). Journal of Food Composition and Analyses, 5:35-68.

\section{Linnemann A and Dijkstra} D (2002):

Toward sustainable production of protein- rich foods: Appraisal of eight crops for Western Europe. Part I. Analysis of the primary links of the production chain. Crit. Rev. Food Sci. Nutr., 42(4): 377-401.

\section{Lorenz K; Gifford $H$ and} Johnson, D L (1993):

Quinoa in pasta products. Developments in Food Science, 37: 1031-1041.

\section{Lorenz K; Coulter L and} Johnson D (1995):

Functional and sensory characteristics of quinoa in foods. Developments in Food Science, 37:1031-1041.

\section{Marconi $E$ and Carcea $M$ (2001): \\ Pasta from nontraditional raw materials. Cereal Food World 46(11):522-30.}

Mastromatteo M; Chillo S; Iannetti M; Civica $\mathrm{V}$ and Del Nobile MA (2011): 
Evaluation of quinoa (Chenopodium quinoa Willd.) flour fortification on the quality of pasta production

Mona Y. Mostafa

Formulation

optimization of glutenfree functional spaghetti based on quinoa, maize and soy flours. Int $J$ Food Sci Tech., 46:1201-1208.

Mc Clave JT and Benson, PG (1991):

Statistical for business and economics. Maxwell Macmillan International editions. Dellen Publishing Co. USA, 272-295.

Monge L; Cortassa G; Fiocchi F; Mussino G and Carta Q (1990):

Glyco-insulinaemic response, digestion and intestinal absorption of the starch contained in two types of spaghetti. Diabetes, Nutrition and Metabolism, 3: 239-246.

Nielsen MA; Sumner AK and Whalley LL (1980):

Fortification of pasta with pea flour and air- classified pea protein concentrate. Cereal Chem., 57(3):203-6

Nsimba RY; Kikuzaki H and Konishi Y (2008):

Antioxidant activity of various extracts

fractions

of

Chenopodium quinoa and Amaranthus spp. seeds. Food Chem., 106:760-766.

Ogungbenle HN (2003):

Nutritional evaluation and functional properties of quinoa (Chenopodium quinoa) flour. International Journal of Food Sciences and Nutrition, 54 (2): 153158.

Osorio DP; Acevedo AE and Vinalay MM (2008):

Pasta added with chickpea flour: Chemical composition, In vitro starch digestibility and 
Evaluation of quinoa (Chenopodium quinoa Willd.) flour fortification on the quality of pasta production

Mona Y. Mostafa

predicted glycemic index.

Petitot M; Boyer L; Minier $C$ and Micard V (2010b):

Fortification of pasta with split pea and faba bean flours: pasta processing and quality evaluation. Food Res Int., 43:634-641.

Rayas-Duarte P; Mock CM and Satterlee LD (1996):

Quality of spaghetti containing buckwheat, amaranth, and lupin flours. Cereal Chem., 73(3):381-87.

\section{Repo - Carrasco R;} Espinoza $C$ and Jacobsen SE (2003):

Nutritional value and use of the Andean crops quinoa (Chenopodium quinoa) andka ${ }^{\sim}$ niwa (Chenopodium pallidicaule). Food Rev Int., 19:179-189 .
Savita S; Arshwinder K; Gurkirat $\mathrm{K}$ and Vikas N (2013):

Influence of different protein sources on cooking and sensory quality of pasta. International Journal of Engineering Research and Applications (IJERA), 3 (2) :17571763.

Su-Chuen N; Anderson A; Coker $J$ and Ondrus $M$ (2007):

Characterization of lipid oxidation products in quinoa (chenopodium quinoa). Food Chem 101(1):185-92.

Svec M; Hru"ková T; Hofmanová $M$ and Vítová (2011):

Quinoa - Wholemeal Flour for Cereal Products. Food Process, Bioprocessing and Food Quality Management. Nantes, France - April 18-20. 
Evaluation of quinoa (Chenopodium quinoa Willd.) flour fortification on the quality of pasta production

Mona Y. Mostafa

\begin{tabular}{l}
\hline Tang C; Hsieh F; \\
Heymann H and Huff HE \\
(1999): \\
Analyzing and \\
correlating instrumental \\
and sensory data: a \\
multivariate study of \\
physical properties of \\
cooked wheat noodles. $J$ \\
Food Quality, \\
22(2):193-211.
\end{tabular}

\section{Ugarcic-Hardi}

Z;

Hackenberger D; Subaric

D and Hardi J (2003):

Effect of soy, maize and extruded maize flour addition on physical and sensory characteristics of pasta. Ital J Food Sci., 15:277-286.

\section{USDA (United States}

\section{Department}

of Agriculture) (2013):

National Nutrient

Database for Standard Reference, Release 26. [Internet]: U.S.

Department of

Agriculture; [2014

March 3]. Available from:

http://www.ars.usda.gov /ba/bhnrc/ndl.

Wood JA (2009):

Texture, processing and organoleptic properties of chickpea-fortified spaghetti with insights to the underlying mechanisms of traditional durum pasta quality. $J$ Cereal Sci., 49:128-33.

\section{Young-Soo- Kim (1998):}

Quality of wet noodles prepared with wheat flour and mushroom powder. Korean J Food SciTechnol., 30:13731380.

Zhao YH; Manthey FA; Chang SK; Hou $H$ and Yuan SH (2005):

Quality characteristics of spaghetti as affected by green and yellow pea, lentil, and chickpea flours. $J$ Food Sci., 70(6):S371-76. 
Evaluation of quinoa (Chenopodium quinoa Willd.) flour fortification on the quality of pasta production

Mona Y. Mostafa

Table (1): Chemical composition of raw materials:

\begin{tabular}{|c|c|c|c|c|c|c|}
\hline \multirow{2}{*}{ Samples } & \multicolumn{6}{|c|}{ Parameters } \\
\cline { 2 - 7 } & Moisture & Protein & T. fat & T. ash & Carbohydrates & Fiber \\
& $\%$ & $\%$ & $\%$ & $\%$ & $\%$ & $\%$ \\
\hline Semolina & $10.81 \pm$ & $13.10 \pm$ & $3.36 \pm$ & $5.43 \pm$ & $67.29 \pm$ & $6.31 \pm$ \\
flour & 0.70 & 0.50 & 0.07 & 0.01 & 1.25 & 0.15 \\
\hline Quinoa & $10.78 \pm$ & $13.99 \pm$ & $3.87 \pm$ & $6.08 \pm$ & $65.44 \pm$ & $7.14 \pm$ \\
flour & 0.07 & 0.14 & 0.01 & 0.02 & 0.39 & 0.08 \\
\hline
\end{tabular}

Table (2): Effect of quinoa flour fortification on farinograph parameters of pasta dough

\begin{tabular}{|l|c|c|c|c|c|c|}
\hline Samples & $\begin{array}{c}\text { Water } \\
\text { absorption } \\
(\%)\end{array}$ & $\begin{array}{c}\text { Arrival } \\
\text { time } \\
(\mathrm{min})\end{array}$ & $\begin{array}{c}\text { Dough } \\
\text { development } \\
\text { time } \\
(\mathrm{min})\end{array}$ & $\begin{array}{c}\text { Dough } \\
\text { stability } \\
(\mathrm{min})\end{array}$ & $\begin{array}{c}\text { Mixing } \\
\text { tolerance } \\
\text { index } \\
(\mathrm{BU})\end{array}$ & $\begin{array}{c}\text { Dough } \\
\text { weakening } \\
(\mathrm{BU})\end{array}$ \\
\hline Control & 57.5 & 7.0 & 11.0 & 11 & 20 & $\mathbf{6 0}$ \\
\hline $\begin{array}{l}10 \% \\
\text { QFP }\end{array}$ & 57.5 & 4.5 & 8.0 & 10.0 & 25 & $\mathbf{7 0}$ \\
\hline $\begin{array}{l}20 \% \\
\text { QFP }\end{array}$ & 60.5 & 5.5 & 7.5 & 9.0 & 35 & $\mathbf{8 0}$ \\
\hline $\begin{array}{l}30 \% \\
\text { QFP }\end{array}$ & $\mathbf{6 2 . 5}$ & $\mathbf{5 . 0}$ & $\mathbf{7 . 0}$ & $\mathbf{7 . 5}$ & $\mathbf{6 0}$ & $\mathbf{1 0 0}$ \\
\hline
\end{tabular}

QFP: Quinoa flour pasta 
Evaluation of quinoa (Chenopodium quinoa Willd.) flour fortification on the quality of pasta production

Mona Y. Mostafa

Table (3): Effect of quinoa flour fortification on color characteristics of pasta

\begin{tabular}{|c|c|c|c|}
\hline \multicolumn{4}{|c|}{ Color parameters of Flour mixture } \\
\hline Samples & $\mathbf{L}^{*}$ & $\mathbf{a}^{*}$ & $\mathbf{b}^{*}$ \\
\hline Control & $85.40 \pm 0.21 \mathrm{a}$ & $2.25 \pm 0.03 a$ & $20.85 \pm 0.10 a$ \\
\hline $\begin{array}{l}10 \% \text { quinoa } \\
\text { flour pasta }\end{array}$ & $83.81 \pm 0.11 \mathrm{~b}$ & $1.95 \pm 0.05 b$ & $19.15 \pm 0.07 b$ \\
\hline $\begin{array}{l}20 \% \text { quinoa } \\
\text { flour pasta }\end{array}$ & $82.47 \pm 0.07 \mathrm{~b}$ & $1.70 \pm 0.03 \mathrm{c}$ & $17.88 \pm 0.09 \mathrm{c}$ \\
\hline $\begin{array}{l}30 \% \text { quinoa } \\
\text { flour pasta }\end{array}$ & $81.55 \pm 0.04 \mathrm{c}$ & $1.41 \pm 0.04 \mathrm{~d}$ & $16.80 \pm 0.09 \mathrm{~d}$ \\
\hline LSD at 0.05 & 2.150 & 0.244 & 0.522 \\
\hline \multicolumn{4}{|c|}{ Color parameters of Processed pasta before drying } \\
\hline Samples & $\mathbf{L} *$ & $\mathbf{a}^{*}$ & $\mathbf{b}^{*}$ \\
\hline Control & $77.61 \pm 0.28 \mathrm{a}$ & $1.89 \pm 0.035 \mathrm{c}$ & $20.05 \pm 0.05 b$ \\
\hline $10 \% \mathrm{QFP}$ & $73.22 \pm 0.45 b$ & $1.80 \pm 0.02 \mathrm{c}$ & $19.26 \pm 0.02 c$ \\
\hline $20 \% \mathrm{QFP}$ & $62.49 \pm 0.09 c$ & $2.43 \pm 0.06 \mathrm{~b}$ & $20.83 \pm 0.07 a$ \\
\hline $30 \%$ QFP & $62.02 \pm 0.07 c$ & $2.57 \pm 0.07 a$ & $21.35 \pm 0.07 a$ \\
\hline LSD at 0.05 & 0.775 & 0.274 & 0.547 \\
\hline \multicolumn{4}{|c|}{ Color parameters of Processed pasta after drying } \\
\hline Samples & $\mathbf{L} *$ & $\mathbf{a}^{*}$ & $\mathbf{b}^{*}$ \\
\hline Control & $77.01 \pm 0.381 \mathrm{a}$ & $2.16 \pm 0.07 c$ & $19.55 \pm 0.14 \mathrm{c}$ \\
\hline $10 \% \mathrm{QFP}$ & $70.11 \pm 0.139 b$ & $3.07 \pm 0.120 \mathrm{~b}$ & $22.97 \pm 0.56 b$ \\
\hline $20 \%$ QFP & $66.15 \pm 0.302 c$ & $3.42 \pm 0.124 a$ & $23.57 \pm 0.03 b$ \\
\hline $30 \% \mathrm{QFP}$ & $63.55 \pm 1.53 \mathrm{~d}$ & $3.45 \pm 0.07 \mathrm{a}$ & $24.09 \pm 0.07 a$ \\
\hline LSD at 0.05 & 2.071 & 0.290 & 1.107 \\
\hline \multicolumn{4}{|c|}{ Color parameters of Cooked pasta } \\
\hline Samples & $\mathbf{L} *$ & $\mathbf{a}^{*}$ & $\mathbf{b}^{*}$ \\
\hline Control & $71.17 \pm 0.55 a$ & $0.66 \pm 0.01 d$ & $17.19 \pm 0.07 c$ \\
\hline $10 \% \mathrm{QFP}$ & $62.17 \pm 0.23 b$ & $1.62 \pm 0.02 \mathrm{c}$ & $18.40 \pm 0.07 \mathrm{a}$ \\
\hline $20 \%$ QFP & $59.38 \pm 0.35 c$ & $2.31 \pm 0.02 b$ & $17.66 \pm 0.05 b$ \\
\hline $30 \%$ QFP & $53.67 \pm 0.32 \mathrm{~d}$ & $2.53 \pm 0.04 \mathrm{a}$ & $17.16 \pm 0.07 \mathrm{c}$ \\
\hline LSD at 0.05 & 2.574 & 0.192 & 0.421 \\
\hline
\end{tabular}

QFP: Quinoa flour pasta, $L^{*}$ : luminosity, $a^{*}$ : red intensity, and $b^{*}$ : yellow intensity 
Evaluation of quinoa (Chenopodium quinoa Willd.) flour fortification on the quality of pasta production

Mona Y. Mostafa

Table (4): Effect of quinoa flour fortification on cooking quality of pasta

\begin{tabular}{|c|c|c|c|}
\hline Samples & Weight increase & Volume increase & Cooking loss \\
& $(\%)$ & $(\%)$ & $3.5 \pm 0.14 \mathrm{~d}$ \\
\hline Control & $220 \pm 2.82 \mathrm{~d}$ & $165 \pm 4.42 \mathrm{~d}$ & $5.00 \pm 0.21 \mathrm{c}$ \\
\hline $10 \%$ QFP & $235 \pm 3.00 \mathrm{c}$ & $180 \pm 3.20 \mathrm{c}$ & $6.5 \pm 0.28 \mathrm{~b}$ \\
\hline $20 \%$ QFP & $255 \pm 4.32 \mathrm{~b}$ & $195 \pm 5.60 \mathrm{~b}$ & $7.5 \pm 0.42 \mathrm{a}$ \\
\hline $30 \%$ QFP & $275 \pm 5.33 \mathrm{a}$ & $210 \pm 3.55 \mathrm{a}$ & 0.791 \\
\hline LSD at 0.05 & 12.801 & 12.453 & \\
\hline
\end{tabular}

QFP: Quinoa flour pasta

Table (5): Effect of quinoa flour fortification on organolyptic characteristics of pasta

\begin{tabular}{|c|c|c|c|c|c|c|}
\hline Samples & $\begin{array}{c}\text { Color } \\
(10)\end{array}$ & $\begin{array}{c}\text { Flavor } \\
(10)\end{array}$ & $\begin{array}{c}\text { Mouthfeel } \\
(10)\end{array}$ & $\begin{array}{c}\text { Elasticity } \\
(10)\end{array}$ & $\begin{array}{c}\text { Overall } \\
\text { acceptability } \\
(10)\end{array}$ & $\begin{array}{c}\text { Total } \\
(50)\end{array}$ \\
\hline Control & $9.75 \pm$ & $9.83 \pm$ & $9.70 \pm$ & $9.81 \pm$ & $9.55 \pm$ & $47.81 \pm$ \\
& $0.35 \mathrm{a}$ & $0.28 \mathrm{a}$ & $0.23 \mathrm{a}$ & $0.25 \mathrm{a}$ & $0.52 \mathrm{a}$ & $1.02 \mathrm{a}$ \\
\hline $10 \%$ QFP & $8.9 \pm$ & $9.33 \pm$ & $9.01 \pm$ & $8.50 \pm$ & $8.95 \pm$ & $44.18 \pm$ \\
& $0.42 \mathrm{a}$ & $0.57 \mathrm{a}$ & $0.42 \mathrm{a}$ & $0.35 \mathrm{~b}$ & $0.46^{\mathrm{a}}$ & $1.25 \mathrm{~b}$ \\
\hline $20 \%$ QFP & 7.65 & 9.11 & $8.10 \pm$ & $7.13 \pm$ & $7.13 \pm$ & $42.25 \pm$ \\
& $\pm 0.35 \mathrm{~b}$ & $\pm 0.28 \mathrm{a}$ & $0.35 \mathrm{~b}$ & $0.41 \mathrm{c}$ & $0.37 \mathrm{~b}$ & $0.88 \mathrm{c}$ \\
\hline $30 \%$ QFP & 7.20 & 8.26 & $6.70 \pm$ & $6.50 \pm$ & $6.04 \pm$ & 38.66 \\
& $\pm 1.41 \mathrm{~b}$ & $\pm 0.64 \mathrm{~b}$ & $0.32 \mathrm{c}$ & $0.62 \mathrm{~d}$ & $0.35 \mathrm{c}$ & $\pm 1.52 \mathrm{~d}$ \\
\hline LSD at 0.05 & 0.9311 & 0.8996 & 0.9211 & 0.9621 & 0.8621 & 2.207 \\
& & & & & & \\
\hline
\end{tabular}

QFP: Quinoa flour pasta 
Evaluation of quinoa (Chenopodium quinoa Willd.) flour fortification on the quality of pasta production

Mona Y. Mostafa

Table (6): Effect of quinoa flour fortification on texture profile of dried and cooked pasta

\begin{tabular}{|c|c|c|c|c|c|}
\hline \multicolumn{6}{|c|}{ Dried pasta } \\
\hline Samples & $\begin{array}{c}\text { Hardness } \\
(\mathbf{N})\end{array}$ & $\begin{array}{c}\text { Deformation } \\
\text { at hardness } \\
(\mathbf{m m})\end{array}$ & $\begin{array}{c}\text { Hardness } \\
\text { work } \\
(\mathbf{m J})\end{array}$ & $\begin{array}{c}\text { Peak } \\
\text { Stress } \\
\text { Dyn/cm }\end{array}$ & $\begin{array}{c}\text { Fracturability } \\
\text { with 1\% of } \\
\text { load } \\
\text { sensetivity } \\
(\mathbf{N})\end{array}$ \\
\hline Control & 17.55 & 0.23 & 0.80 & 55904152 & 17.55 \\
\hline $10 \%$ QFP & 32.30 & 2.15 & 3.20 & 102876128 & 1.93 \\
\hline $20 \%$ QFP & 34.32 & 1.87 & 4.70 & 109309792 & 1.13 \\
\hline $30 \%$ QFP & 48.32 & 0.49 & 3.00 & 153876960 & 48.32 \\
\hline Control & 3.02 & 1.61 & 3.40 & 9619262 & 3.02 \\
\hline $10 \%$ QFP & 3.47 & 1.62 & 1.10 & 11055905 & 3.47 \\
\hline $20 \%$ QFP & 3.86 & 1.98 & 1.30 & 12305160 & 0.07 \\
\hline $30 \%$ QFP & 4.09 & 1.73 & 1.30 & 13023481 & 4.09 \\
\hline
\end{tabular}

QFP: Quinoa flour pasta Hardness $=$ The maximum force of the 1 st compression 
Evaluation of quinoa (Chenopodium quinoa Willd.) flour fortification on the quality of pasta production

Mona Y. Mostafa

Table (7): Effect of quinoa flour fortification on chemical composition of pasta

\begin{tabular}{|c|c|c|c|c|c|c|}
\hline Samples & $\begin{array}{c}\text { Moisture } \\
\%\end{array}$ & $\begin{array}{c}\mathrm{C} . \\
\text { protein } \\
\%\end{array}$ & $\begin{array}{c}\text { T.fat } \\
\%\end{array}$ & $\begin{array}{c}\text { T.ash } \\
\%\end{array}$ & $\begin{array}{c}\mathrm{T} . \\
\text { carbohydrates } \\
\%\end{array}$ & $\begin{array}{c}\text { C. } \\
\text { fiber } \\
\%\end{array}$ \\
\hline Control & $\begin{array}{c}12.81 \pm \\
0.19 \mathrm{a}\end{array}$ & $\begin{array}{l}9.13 \pm \\
0.07 d\end{array}$ & $\begin{array}{l}1.19 \pm \\
0.03 \mathrm{~d}\end{array}$ & $\begin{array}{l}2.97 \pm \\
0.12 d\end{array}$ & $\begin{array}{c}73.88 \pm \\
0.35 \mathrm{a}\end{array}$ & $\begin{array}{l}2.04 \pm \\
0.01 d\end{array}$ \\
\hline $10 \%$ QFP & $\begin{array}{c}12.43 \pm \\
0.03 b\end{array}$ & $\begin{array}{c}10.07 \pm \\
0.07 \mathrm{c}\end{array}$ & $\begin{array}{l}1.71 \pm \\
0.07 \mathrm{c}\end{array}$ & $\begin{array}{l}3.54 \pm \\
0.09 \mathrm{c}\end{array}$ & $\begin{array}{c}72.23 \pm \\
0.29 \mathrm{~b}\end{array}$ & $\begin{array}{l}3.10 \pm \\
0.02 \mathrm{c}\end{array}$ \\
\hline $20 \%$ QFP & $\begin{array}{c}12.06 \pm \\
0.3 \mathrm{c}\end{array}$ & $\begin{array}{c}11.19 \pm \\
0.22 b\end{array}$ & $\begin{array}{l}2.23 \pm \\
0.07 \mathrm{~b}\end{array}$ & $\begin{array}{l}4.13 \pm \\
0.01 b\end{array}$ & $\begin{array}{c}70.36 \pm \\
0.33 \mathrm{c}\end{array}$ & $\begin{array}{l}4.17 \pm \\
0.07 \mathrm{~b}\end{array}$ \\
\hline $30 \%$ QFP & $\begin{array}{c}11.47 \pm \\
0.02 \mathrm{~d}\end{array}$ & $\begin{array}{c}12.36 \pm \\
0.01 \mathrm{a}\end{array}$ & $\begin{array}{l}2.80 \pm \\
0.10 \mathrm{a}\end{array}$ & $\begin{array}{l}4.78 \pm \\
0.05 \mathrm{a}\end{array}$ & $\begin{array}{c}68.57 \pm \\
0.14 \mathrm{~d}\end{array}$ & $\begin{array}{l}5.27 \pm \\
0.08 \mathrm{a}\end{array}$ \\
\hline
\end{tabular}

QFP: Quinoa flour pasta 


\section{تقييم أثز التدعيم بدقيق الكينوا على خواص جودة إنتاج المكرونة المئة}

منى ياسر عبد الخالق مصطفى

قسم الاقتصاد المنزلى- كلية التربية النوعية - جامعة المنصورة - مصر الملخص العربي

استعهفت الدراسة تقبيم أثر التدعيم بنسب مختلفه من دقيق الكينوا على جودة إنتاج

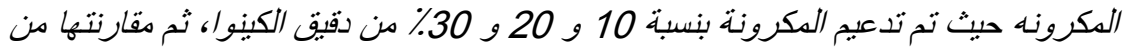

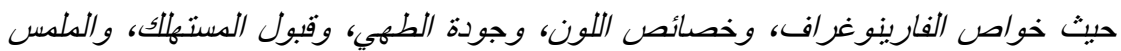

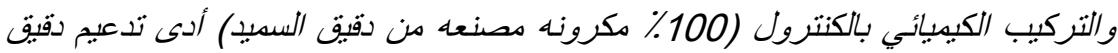

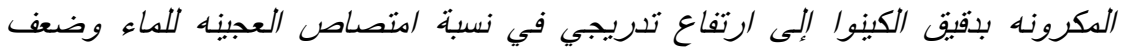

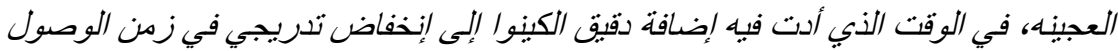

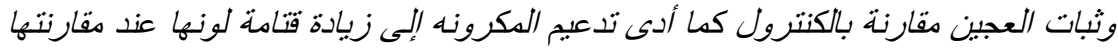

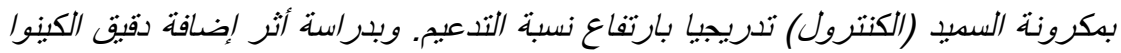

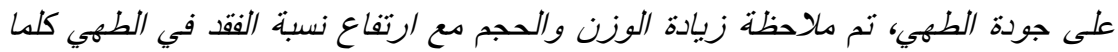

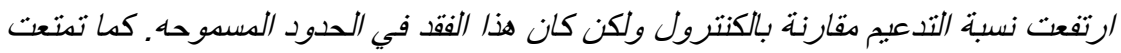

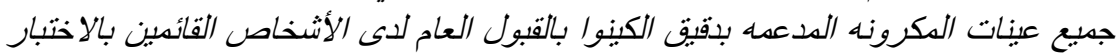

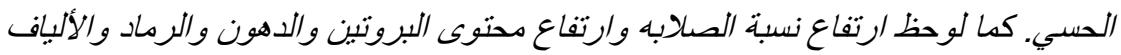

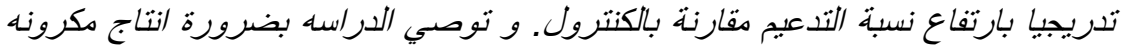

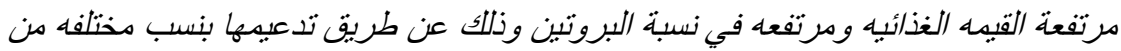
دقيق الكبيوا. الكلمات المفتاحية: المكرونه ـ الكينوا ـ الفارينوجراف - جودة الطهي ـ الصلابه. 